\title{
LA RETÓRICA DE LOS ANTIGUOS MEXICANOS COMO INSTRUMENTO PARA SU CONVERSIÓN AL CRISTIANISMO
}

\author{
Sandra Anchondo Pavón \\ Universidad Panamericana \\ sanchondo@up.edu.mx
}

\begin{abstract}
This work is about the General History of the Things of New Spain in its complete and definitive version known as the Florentine Codex of 1557. It is our belief that Sahagún formulated a three language vocabulary (based in Nebrija's Latin-Spanish dictionary as well as the one made by his companion Alonso de Molina) and an encyclopedic dictionary (never concluded) influenced by Ambrosio Calepino's style for his preaching of the Gospel project. Finally, the organization of his known History fulfilled with a treatise which proposed both: the recognition of the Mexican language as a classic and the recompilation of all the poetical and rhetorical works in order to withdraw the vocabulary as well as these villages' life style before the Conquest.

Key Words: Ancient Mexicans, Religious converts, preaching of the Gospel, native literature, rhetoric.
\end{abstract}

\section{Resumen}

Esta investigación se centra en la Historia Universal de las cosas de Nueva España en su versión más completa y definitiva, el Códice Florentino de 1577. Creemos que Sahagún planeó un vocabulario trilingüe (con base en el diccionario latino-español de Nebrija como hiciera su cofrade Alonso de Molina) y continuó, en medio de su proyecto evangelizador, con la idea (que no concretó) de hacer un diccionario enciclopédico al estilo de Ambrosio Calepino. Finalmente culminó la estructuración de su conocida Historia como un tratado literario que proponía la "clasicalización" de la lengua mexicana y la recopilación de sus formas poéticas y retóricas, con el fin de tener un texto base desde el cual extraer no sólo los vocablos sino el imaginario de estos pueblos antes de la conquista.

Palabras clave: antiguos mexicanos, conversión, discurso, evangelización, literatura indígena.

Recibido: 06-12-07. Aceptado: 01-04-08. 
Los doce primeros franciscanos que vinieron al Nuevo Mundo en $1524^{1}$ se comunicaron desde su llegada con algunos tlamatinime, ${ }^{2}$ estableciendo con ellos un diálogo pacífico, aunque lleno de discrepancias, sobre sus creencias religiosas.

Este primer contacto de aparente confusión e incomprensión, ${ }^{3}$ fue relatado por Bernardino de Sahagún (observante que llegó a América cinco años más tarde), en el célebre Coloquio de los doce. Dicha obra constituye una reconstrucción cuasidramática ${ }^{4}$ del primer encuentro entre los frailes europeos y los sabios indígenas, por el significado trascendental y arquetípico que el autor le otorga al reconstruir una comunicación inicial sorprendentemente afable, a través del diálogo entre los franciscanos y los sátrapas indios, quienes terminan aceptando atender a los frailes. Así sus palabras:

El sancto padre en la tierra, el gran gobernante en las cosas espirituales, nos envió a nosotros

(a nosotros doce)

nos ordenó

que, con la palabra divina,

os viniéramos a hacer conocer a él, el solo único, Dios verdadero, que gobierna. Dador de la vida,

${ }^{1}$ Aunque otras órdenes como los dominicos en 1526 y los agustinos en 1533, tuvieron que ver en la labor evangelizadora de América, los franciscanos además de los primeros en llegar al continente para estos fines, fueron los más prolíficos estudiosos de la cultura aborigen, ello se ve en sus escritos etnográficos, lingüísticos y doctrinales.

${ }^{2}$ Término náhuatl que designa a los teólogos y filósofos prehispánicos.

${ }^{3}$ Cfr. Daniéle Dehouve: "Un diálogo de sordos: los coloquios de Sahagún”, Estudios de cultura náhuatl, 33 (2002), pp. 185-216.

${ }^{4}$ Así lo ha considerado Jesús Bustamante cuando afirma que el coloquio "reconstruye de forma arquetípica y con un formidable estilo retórico un momento fundacional". Jesús Bustamante: "Retórica, traducción y responsabilidad histórica: claves humanísticas en la obra de Bernardino de Sahagún", en Humanismo y visión del otro en la España moderna, Madrid: CSIC 1992, p. 269. 
dueño del cerca y el junto, dueño del cielo, de la superficie de la tierra, que inventó, que hizo, los cielos, la tierra, y la región de los muertos.

Y tal vez diréis ahora que sólo en vano, que para nada cuenta vuestra misión, que en vano habéis venido, porque (diréis) nosotros también tenemos allá a nuestro dios,

también allí a los que son gobernantes nuestros, también nosotros tenemos conocido, nosotros prestamos atención, nosotros reverenciamos, y obedecemos, servimos, a aquél que también llamamos, por quien se vive. delante de él acercamos tierra a la boca nos manifestamos llanamente (hacemos confesión), quemamos copal, ofrecemos papel, ayunamos [...]

En verdad nosotros sabemos, hemos visto y hemos escuchado que vosotros, no ya uno, sino muy muchos, tan numerosos son los que tenéis por dioses, a los que honráis, a los que servís $[\ldots]^{5}$

\footnotetext{
${ }^{5}$ Por cierto, Sahagún piensa que los indios fueron monoteístas. Lo dice expresamente en una carta inédita escrita a san Pío V el 25 de diciembre de 1570, que se encuentra en el Archivo Secreto Vaticano: “entre los philosophos antiguos unos dixeron que ninun dios avia y desta opinion fueron muchos: Ximocrates dixo que avia ocho dioses y nomas. Antistenes dixo que avia muchos dioses populares, pero solo un todo poderoso criador y governador de todas las cosas. Esta opinión o creencia es la que e hallado en toda esta nueva españa. Tienen que ay un Dios que es puro espíritu, todopoderoso, cria-
} 
Pero si fueran dioses verdaderos, si de verdad fueran el Dador de la vida, ¿Por qué mucho se burlan de la gente? ¿Por qué, de ella hacen mofa? ¿Por qué no tienen compasión de los que son hechuras suyas? ¿Por qué también ellos, muchas, sin número, enfermedades, aflicciones, a vosotros os causan? [...] pero aquél, que es Dios verdadero, que gobierna, verdadero inventor de la gente, el verdadero Dador de la vida, el verdadero Dueño del cerca y del junto, aquél que nosotros os venimos a mostrar, él no es así ${ }^{6}$.

Y luego el cuestionamiento de los señores nahuas:

¿Acaso aquí, delante de vosotros, debemos destruir la antigua regla de vida? ${ }^{7}$ ¿La que en mucho tuvieron, nuestros abuelos, nuestras abuelas, la que mucho ponderaron, la que mantuvieron con admiración $[\ldots]$ ?

dor y gobernador de todas las cosas [...] A este atribuyan toda sabiduría y hermosura y bienaventuranza". Archivo Secreto Vaticano, A. A. Arm. I - XVIII, 1816, Cartaceo. Folios 3 y $3 \mathrm{v}$.

${ }^{6}$ Bernardino de SAHAGÚN: Coloquios y doctrina cristiana con que los doce frailes de San Francisco, enviados por el papa Adriano VI y por el emperador Carlos V, convirtieron a los indios de la Nueva España, ed. Miguel León Portilla, México: UNAM 1986, capítulo IV, C. 357 y ss. pp. 121-125. En adelante citado como CD.

${ }^{7}$ En náhuatl se lee veve tlamanjtiliztlj es decir, huehue tlamanitiliztli concepto con el que se denotan las tradiciones y normas morales. 
Al final describe el deseo de filiación de los más sabios a la Iglesia católica ${ }^{8}$ :

Aquí cogemos,

Aquí tomamos

Tal como es, vuestra palabra.

Que no se altere vuestro corazón,

Que esté tranquilo el nuestro.

¿Quiénes son, cómo son,

de dónde vinieron,

aquellos a quienes nosotros tenemos por dioses,

a los que hacemos súplicas??

No me interesa por ahora hablar de la historicidad del diálogo, si éste ocurrió o no en la realidad, o si tuvo lugar en otros términos distintos a los que relata Sahagún son cuestiones ya discutidas, ${ }^{10}$ lo que me interesa es observar cómo el autor recurre a las autoridades indígenas para apoyarse en ellas en la transmisión de la nueva religión, sobre todo me llama la atención que las retome con el fin de proponer a la antigua religión indiana como basamento de la cristiana ${ }^{11}$.

Cuando el leonés recupera los Coloquios, ha pasado mucho tiempo en convivencia con los indios (cuarenta años); entre otras cosas, ha descubierto su sensibilidad, su profunda religiosidad y su sentido de la autoridad. Me parece que Sahagún se siente llamado a reconstruir de manera dramática y arquetípica el diálogo inicial entre sacerdotes indígenas y españoles como propuesta esperanzadora de la convivencia entre dos culturas pero bajo el triunfo de lo que él consideraba la verdadera religión.

La obra Coloquios y doctrina cristiana fue escrita en español (y posteriormente traducida al mexicano para 1564). Este interés de Sahagún

\footnotetext{
${ }^{8}$ Autoridad moral a quienes los demás siguen...

${ }^{9}$ CD, capítulo VIII, C. 1155-1165, p. 161.

${ }^{10}$ Cfr. Miguel LEÓn-Portilla: “Estudio introductorio", en CD, pp. 23-26.

${ }^{11}$ Cfr. CD, pp. 23-29.
} 
por traducirla al náhuatl refleja su forma de encarar las misiones en América, pues el Coloquio "ofrece con un máximo grado de autorización un modelo y un instrumento de predicación"; 12 es así que Sahagún muestra en este diálogo prototípico los modos con que las nuevas generaciones de misioneros podían tratar de convertir a los indios, recuperando la autoridad de los sabios indígenas y su palabra.

Bernardino ha descubierto una maniobra de adaptación ${ }^{13}$ operante sobre todo en el ámbito discursivo y pragmático, por medio de la cual, entendían los conceptos y enseñanzas europeas a través de lo ya conocido y predicho por los antepasados (Klor de Alva ha llamado a esta estrategia la contranarrativa de la continuidad); Sahagún mismo se sirve de ello para sus propios fines, retomando la palabra de los viejos para afirmar o negar las nuevas verdades:

Lo tercero que estimaban los ancianos, vuestros abuelos, lo que decían era digno de estima, eran los que han sido anegados y también los que han sido heridos por rayos. Decían que estos eran buenos, rectos, de corazones limpios; por eso los amaban los tlaloque; los llevaban a su casa allá en Tlalocan para que viviesen con ellos. Todas estas son palabras mentirosas [...] La sexta cosa que al irse declararon los ancianos es que decían que los de buen corazón, las personas de confianza, son respetadas, son honradas, son irreprensibles, en ningún lugar son reprensibles, y viven contentas, viven tranquilas; en ningún lugar temen lo que está

\footnotetext{
${ }^{12}$ Bustamante: "Retórica, traducción y responsabilidad histórica... ”, p. 269.

${ }^{13}$ Que otros han considerado una maniobra de "resistencia". Grosso modo la idea de Klor de Alva pudiera considerarse como la expongo aquí, sin embargo la equivalencia no es del todo precisa por lo que sugiero confrontar su texto completo: "la contranarrativa de la continuidad. Creo que el objetivo (real, si bien no siempre consciente) de esta maniobra discursiva era domesticar los objetos, actos e ideas europeas al ligarlas a los objetivos, prácticas e instituciones indígenas". Jorge KLOR DE ALVA: "El discurso nahua y la apropiación de lo europeo" en De palabra y obra en el Nuevo mundo. Imágenes interétnicas, ed. Miguel León Portilla, México: Siglo XXI 1992, p. 341.
} 
detrás de ellas, viven seguras. Lo que así decían los ancianos es la pura verdad: que así eran amadas en el mundo ${ }^{14}$.

En términos generales, su propia visión del mundo y de la vida, ayudó a los indígenas a sobreponerse con naturalidad a la ruptura y la imposición extranjera, pues fue el fundamento de su apertura y a fin de cuentas, receptáculo de las nuevas visiones, buscando puntos en común o puntos conciliables por ejemplo, prevaleció su sentido de autoridad, la importancia de la palabra, la religiosidad profunda y cierto pragmatismo moral. Aunque por otro lado, pudiera pensarse que tuvieron que abandonar sus creencias sobre la predictibilidad futura y el eterno retorno, las cuales fueron la base para comprender la nueva historicidad lineal y cristiana $^{15}$.

A la luz de esta concepción del mundo, los acontecimientos sociopolíticos ocurridos tras la aparición de los europeos podrían reconstruirse sobre un continuo histórico y cultural que, a nuestros ojos, difuminaría las diferencias entre el pasado indígena y el presente colonial ${ }^{16}$.

La incorporación del mundo europeo a su propio mundo y el uso de la lengua náhuatl, permitía, al mismo tiempo, la conservación de varios elementos de su propia cosmovisión y la adaptación política y social que deseaban los españoles. De tal suerte podemos decir que al poner en alfabeto europeo ${ }^{17}$ un diálogo en náhuatl y español, Sahagún pretendió,

\footnotetext{
${ }^{14}$ Bernardino de SAHAgún: "Apéndice a la postilla", en Adiciones, Apéndice a la postilla y Ejercicio cotidiano, ed. J.O Anderson, México: UNAM 1993, pp. 95-97.

${ }^{15}$ Tomemos como ejemplo el hecho de que en ambas culturas se afirmaba que había señales que anunciaban el futuro, aunque éstas no fueran de la misma naturaleza en cada caso, la creencia en presagios fue retomada de la tradición prehispánica para explicar los elementos que debían extirparse y los que debían conservarse en aras de la inculturación del cristianismo. Cfr. Miguel Pastrana Flores: Historias De la conquista, México: UNAM 2004, pp. 25-63.

${ }^{16}$ Klor DE ALVA, p. 349.

${ }^{17}$ El tema del trasvase de los discursos orales nahuas al alfabeto latino ha sido abordado a profundidad por Patrick JoHAnsson: La palabra de los aztecas, México: Trillas 2000 , p. 34.
} 
como vemos en toda su obra, facilitar los objetivos misionales, sin un cambio propiamente cultural ${ }^{18}$. La cita siguiente es clara al respecto,

[S]i aquella manera de regir no estuviera tan inficionada con ritos y supersticiones idolátricas, paréceme que era muy buena, y si limpiada de todo lo idolátrico que tenía y haciéndola del todo cristiana, se introdujese en esta república indiana y española, cierto sería gran bien y sería causa de librar así a la una república como a la otra de grandes males ${ }^{19}$.

Veamos esta otra:

Fueron, cierto, en estas cosas extremados, devotísimos para con sus dioses, celosísimos de sus repúblicas, entre sí muy urbanos; para con sus enemigos muy crueles; para con los suyos, humanos y severos; y pienso que por estas virtudes alcanzaron el imperio, aunque les duró poco, y ahora todo lo han perdido, como verá claro el que cotejase lo contenido en este libro con la vida que ahora tienen ${ }^{20}$.

\section{II}

Entre muchas virtudes, el texto de los Coloquios representa una ventaja importante para Sahagún, le permite retomar el sentido de autoridad de los indios para su propia conversión y le brinda elementos para justificar los hechos ocurridos en la conquista americana cara a la Historia de la Salvación, ante españoles e indios ${ }^{21}$.

\footnotetext{
${ }^{18}$ Aunque la religiosidad es también un fenómeno cultural, me refiero a que Bernardino, convencido de que ninguna religión puede imponerse por la fuerza, toma la antigua cultura de los indios como cimiento para la evangelización.

${ }^{19}$ Bernardino de SaHagún: Códice Florentino. Edición facsimilar del gobierno de la república del manuscrito 218-20 de la colección Palatina de la biblioteca Medicea Laurenziana, México 1979, libro X, 14. En adelante citado como CF.

${ }^{20} \mathrm{CF}$, prólogo, fol. 297.

${ }^{21}$ Los españoles deseaban entender por qué Dios había permitido tanta injuria en estas tierras y por qué habían permanecido ocultas tanto tiempo, pero también necesi-
} 
El esfuerzo que hace nuestro autor en el Coloquio, ayudado de viejos, sabios y estudiantes, es el primer intento de varios para encontrar herramientas clave hacia la eficacia de la evangelización novohispana, pues con el paso del tiempo y el transcurrir de su propia experiencia - había sido misionero y profesor en el colegio de la Santa Cruz de Tlatelolco-, insiste en los pocos frutos de esta empresa, debido a su escasa contribución para alcanzar su principal finalidad: hacer que los naturales ganasen el reino de los cielos ${ }^{22}$. Bajo esta preocupación nace su Historia general ${ }^{23}$.

Y no es otra cosa por la cual hemos venido, hemos sido enviados. Sólo por compasión de vosotros, por la salvación vuestra $[\ldots]^{24}$ Nada de lo que es terrestre, quiere el gran gobernante en las cosas divinas, bien fueran jades, metales

taban fundamentar que estos indios eran plenos hijos de Dios. Del mismo modo, eventualmente, los indios pidieron explicaciones sobre las orientaciones pragmáticas de sus vidas, ante la nueva idea de una historia universal lineal de la que supuestamente ellos formaban parte desde el inicio de los tiempos.

${ }^{22}$ “Ntro. Señor Dios ha tenido ocultada esta media parte del mundo hasta nuestros tiempos, que por su divina ordenación ha tenido por bien de manifestarla a la iglesia romana católica, no con propósito que fuesen tiranizados sus naturales, sino con propósito que sean alumbrados de las tinieblas de la idolatría en que han vivido, y sean introducidos en la iglesia católica, e informados en la religión cristiana, y para que alcancen el reino de los cielos, muriendo en la fe de verdaderos cristianos". Bernardino de SAHAGÚN: Historia General de las cosas de Nueva España, ed. Ángel María Garibay, México: Porrúa 1999, pp. 719, 720. Al parecer, esta versión ha sido tomada del Códice Tolosa y no del Florentino (versión en la que no aparece este fragmento).

${ }^{23}$ ¿QQué es esto señor Dios, que habéis permitido tanto tiempo, que aquel enemigo del género humano tan a su gusto se enseñorease desta triste y desamparada nación, sin que nadie le resistiese donde con toda libertad derramó toda su ponzoña y todas sus tinieblas?

Señor Dios, esta injuria no solamente es vuestra, pero también de todo el género humano. Y por la parte que me toca, suplico a vuestra majestad que después de haber quitado todo el poder al tirano enemigo, hagáis que donde abundó el delicto abunde la gracia, y conforme a la abundancia de las tinieblas venga la abundancia de la luz sobre esta gente, que tantos tiempos habéis permitido estar supeditada y opresa de tan grande tiranía". $C F$, exclmationes del autor, apéndice al libro I.

${ }^{24} \mathrm{CD}$, F. $125-136$. 
preciosos, o tal vez plumas de quetzal, o cualquier objeto valioso, sólo ya todo es vuestra salvación lo que él quiere ${ }^{25}$.

Aunque el choque de Europa y América sí estuvo cargado de intereses políticos y económicos, aún puede decirse que la preocupación de Sahagún y muchos otros frailes, fue la salvación de todas las almas de los indios. Por ello, angustiado replica en su prólogo al libro I del Códice Florentino: para entonces "los pecados de la idolatría y ritos idolátricos, y supersticiones y agüeros y abusiones y cerimonias idolátricas no son aún perdidas del todo". Después de reconocer la poca prosperidad de la Iglesia en tierras americanas y la falta de eficacia en la evangelización, al revés de Motolinía, denuncia una cristianización apresurada y superficial. Mientras que fray Toribio defiende una "ardiente y generosa fe" de los mexicanos conversos y confía en la acción de la gracia santificante, ${ }^{26}$ Bernardino duda de la conversión de los naturales, pero sobre todo, difiere de su compañero de orden en relación a los métodos de la práctica misional. Como ha resaltado Elsa Cecilia Frost, lo primordial en Sahagún no es la urgencia en las conversiones, sino la solidez y la profundidad de la fe de los nuevos cristianos ${ }^{27}$.

La explicación aparece sutilmente en la obra de nuestro fraile. La cristianización presenta deficiencias porque no puede imponerse sin la convicción auténtica y personal de los neófitos. Ante la necesidad de una conversión sólida, decide sentar las bases sobre las que, a su juicio, debía fundarse la evangelización, proponiendo para ello un nuevo método, fundamentalmente retórico, que va esbozando desde su insistencia en los "primores de la lengua mexicana", en sus muchas "y muy hermosas metáforas”, en su defensa de la predicación en lengua indígena, en la traducción de textos bíblicos al mexicano ${ }^{28}$ y en el reconocimiento de

\footnotetext{
${ }^{25}$ Cfr. CD: D. 235-254. Cfr. Francisco Morales: "Los Coloquios de Sahagún: el marco teológico de su contenido", Estudios de Cultura Náhuatl, 32 (2001), p. 177.

${ }^{26}$ Toribio Motolinía: Memoriales, ed. Edmundo O’Gorman, México: UNAM 1971, p. 120.

${ }^{27}$ Cfr. Elsa Cecilia Frost: Historia de Dios en las Indias. Visión franciscana del nuevo mundo, México: Tusquets 2002.

${ }^{28}$ Cfr. Luis GonzÁlez Obregón (ed.): Libros y libreros en el siglo XVI, México: Archivo General de la Nación 2002, p. 82.
} 
la plena capacidad de los indios para adquirir la virtud; cuestiones todas que se traducen en un esfuerzo de énfasis al recoger los discursos retóricos de los propios indios (los cuales serán paradigma — que el mismo Bernardino usa - para la predicación cristiana).

Poco a poco, el leonés va integrando su Historia Universal de las cosas de Nueva España, en la que recoge todas las cosas "divinas y humanas" de la gente mexicana. Como él mismo apunta en su prólogo general, tres son los objetivos principales de esta Historia: reconocer la idolatría y predicar contra ella, ${ }^{29}$ sacar a la luz todos los vocablos de la lengua mexicana ${ }^{30}$ y conocer el quilate de esta gente ${ }^{31}$. Por tanto, el texto puede considerarse una especie de manual para confesores y predicadores pero, desde otras aristas, también como un compendio literario o como texto apologético. La obra, sin embargo, por donde quiera que se estudie, revela dos cuestiones fundamentales que el autor enfrenta: ¿cómo identificar las idolatrías? Y ¿cómo erradicarlas?

El problema era difícil no sólo porque en la Nueva España de Sahagún cada día iba apareciendo más gente infiel e idólatra, "a la cual jamás a [sic] llegado la fama del Santo Evangelio" 32 sino por la diferencia de categorías cognitivas, modos de aprehender el mundo.

Por otro lado fue cosa normal que los indios adoptaran externamente las nuevas formas de religiosidad exigidas por los evangelizadores, que a simple vista parecieran cristianos, repitieran las oraciones y reverencias

\footnotetext{
${ }^{29}$ A decir de Sahagún, el Florentino servirá "para curar enfermedades espirituales", como médico de almas sirve al predicador "para enderezar contra ellos su doctrina" y al confesor "para saber preguntar lo que conviene y entender lo que dixesen tocante a su oficio". Cfr. CF, prólogo general.

30 "Es esta obra como una red barredera para sacar a la luz todos los vocablos desta lengua con sus propias y metafóricas significaciones y todas sus maneras de hablar". Cfr. $C F$, prólogo general.

31 “Aprovechará mucho esta obra para conocer el quilate desta gente mexicana, el cual aún no se ha conocido porque vino sobre ellos aquella maldición”. Cfr. CF, prólogo general.

${ }^{32}$ Bernardino de SAHAgún: Breve compendio de los ritos idolátricos que los indios de esta Nueva España usaban en tiempo de su infidelidad, ed. Guillermo Rousset Banda, presentación, paleografía y notas de María Guadalupe Bosch de Souza. México: s. e. 1990 , p. 3.
} 
e incluso acudieran a los templos, y que, sin embargo, persistiera la idolatría en los ámbitos mas privados y en su intimidad personal.

Los pecados de la idolatría y ritos idolátricos, y supersticiones idolátricas y agüeros y abusiones y cerimonias idolátricas no son aún perdidas del todo. Para predicar contra estas cosas, y aun para saber si las hay, menester es de saber cómo las usaban en tiempo de su idolatría, que por falta de no saber esto en nuestra presencia hacen muchas cosas idolátricas sin que lo entendamos ${ }^{33}$.

Ante esto, el seráfico que estudiamos propone una solución; para intentar entenderla remontémonos hasta 1547, año en que comienza a recoger los primeros escritos de su Historia. Para entonces, Bernardino descubre en los antiguos mexicanos una $\pi \alpha \iota \delta \varepsilon i \alpha$ reforzada por los discursos y una filosofía práctica subyacente en ellos y con ello, me parece, reconoce en los propios modos discursivos de los naturales el puente de comprensión que necesita para acercarse a su pensamiento y sensibilidad.

El tema de la recopilación de textos en el Códice Florentino es bastante complejo ${ }^{34}$. Se trata de escritos de primera mano, fuentes directas, pero seleccionadas y enmendadas por la pluma de un franciscano del siglo XVI. Bernardino logra una síntesis única de relatos y discursos mexicanos que a pesar de todo trasluce su visión franciscana. Diversas complicaciones fueron empañando su pretendida "objetividad", de modo que, además de la limitante de sus propios criterios epistemológicos desde los cuales se estructura la obra, quizás otros criterios ajenos al fraile lo orillaron a dejar implícitas algunas de sus tesis. Como sea, el Códice Florentino no muestra los discursos indianos con plena trans-

\footnotetext{
${ }^{33}$ García Quintana: "Prólogo general”, en CF, p. 61.

${ }^{34}$ “Sahagún escribe sin sus propias palabras, cosa admirable; y, más admirable aún, organiza una enciclopedia con la voz de muchos". Ascensión HernándEZ: "La Historia General de Bernardino de Sahagún a la luz de las Enciclopedias de la tradición grecoromana", en Bernardino de Sahagún quinientos años de presencia, México: UNAM 2002 , p. 57.
} 
parencia $^{35}$ (aunque se pueda argüir el intento de Sahagún por no alterar la información sobre la gente mexicana, cosa que se ve muy claramente en el libro VI donde aparecen los discursos y oraciones de los antiguos cuidadosamente transcritos, y en el XII, ${ }^{36}$ de los hechos históricos referentes a la conquista donde quedan plasmados los contenidos al modo de los naturales).

El franciscano intervino en la edición de estos discursos que componen el Códice. De hecho, su influencia es notoria en algunos fragmentos clave. Sin embargo, lo que algunos pueden ver como un trastocamiento, no lo es tanto, o al menos es muy peculiar porque al estar conformado por tres columnas — una en mexicano, otra que constituye la traducción perifrástica al castellano y la última compuesta por pictogramas_, ${ }^{37} \mathrm{el}$ texto permite distinguir la mediación del religioso y discernir entre los contenidos indianos de los que no lo son. Más aún, el propio Códice Florentino es un diálogo fundacional en sí mismo.

Pese a lo que pueda haber hecho como compilador, vale la pena resaltar que la vía retórica es para Bernardino el modelo en la predicación y también la solución hermenéutica, por semejanza, para la comprensión de los modelos culturales americanos frente a los de Occidente. El tema resulta atractivo; sin embargo, en este trabajo nos centraremos en otro punto: el interés de Sahagún por rescatar las formas y contenidos (que no presenten reminiscencias idolátricas ni de superchería) para que sean los propios discursos de los indios, retocados con mano cristiana, los

${ }^{35}$ Aunque el acceso al pensamiento indiano a través de este texto por la mediación del siglo XVI franciscano es interesante, no lo tratemos aquí por razones obvias de espacio y tiempo.

${ }^{36}$ Gracias a esta situación, León Portilla dibuja en su célebre Visión de los vencidos el imaginario indiano, tan diferente al europeo de entonces. Cfr. La visión de los vencidos. Relaciones indígenas de la conquista, México: UNAM 2007.

${ }^{37}$ Sobre este tema véase José Luis MARTínEZ: El códice florentino y la historia general de Sahagún, México: Archivo General de la Nación 1982. 
que le sirvan para hacerlos transitar de la antigua religión a la nueva fe, ${ }^{38}$ aprovechando que estos indios eran "devotísimos para con sus dioses" 39 .

\section{III}

Afirmar que la retórica cristiana fue el instrumento de instrumentos en las conversiones de América, cuyo estudio fuera imprescindible para la producción de sermones novohispanos tiene poco de novedoso. Sabemos bien que muchos pensadores del siglo XVI compartieron la convicción de que la vía retórica era el camino para mover las voluntades de los indios hacia la nueva fe; ${ }^{40}$ pero lo que aquí me interesa resaltar está en el uso de la propia retórica de los antiguos mexicanos y no de la retórica cristiana para la conversión de los naturales. Es decir, Sahagún, contrario a lo que hacía Valadés, primer mestizo en publicar una obra en Europa, ${ }^{41}$ pensaba que una retórica eficaz para la evangelización debía proceder de la propia retórica mexicana y no de la retórica clásica

\footnotetext{
${ }^{38}$ Los frailes retomaron muchas de las disposiciones y costumbres de los indios como plataformas para la conversión, por ejemplo, al usar los mismos materiales de construcción para sus templos, estructuras y atrios iguales a aquellos en que los indios observaban sus ritos al aire libre, el recurrente uso de imágenes y propias figuras retóricas, etcétera.

${ }^{39} \mathrm{CF}$, prólogo al libro VI.

${ }^{40}$ Es el caso de fray Diego Valadés y Bartolomé de las Casas. Dice el dominico: "Pero la criatura racional tiene una aptitud natural para que se lleve, dirija o atraiga de una manera blanda, dulce, delicada y suave, en virtud de su libre albedrío, para que voluntariamente escuche, voluntariamente obedezca y voluntariamente preste su adhesión y su obsequio a lo que oye. Luego el modo de mover, dirigir, atraer o encaminar a la criatura racional al bien, a la verdad, a la virtud, a la justicia, a la fe pura y a la verdadera religión, ha de ser un modo que esté de acuerdo con el modo, naturaleza, y condición de la misma criatura racional, es decir, un modo dulce, blando, delicado y suave; de manera que de su propio motivo, con voluntad de libre albedrío y con disposición y facultad naturales, escuche todo lo que se proponga y notifique acerca de la fe, de la verdadera religión, de la verdad, de la virtud y de las demás cosas que se refieren a la fe y a la religión." Bartolomé LAS CASAS: Del único modo de atraer a todos los pueblos a la verdadera religión, México: FCE 1975.

${ }^{41}$ Precisamente su Retórica cristiana en 1579. Cfr. Diego VALAdÉs: Retórica cristiana, México: FCE 2003.
} 
cristiana ${ }^{42}$. Lo que hizo el leonés fue volverse un paso atrás en paralelo al trabajo de su cofrade, pues así como fray Diego explica la retórica cristiana con base en los clásicos, Sahagún recoge la oralidad de los indios para transformarla en "literatura clásica" a partir de la cual se pueda extraer la retórica de los mexicanos ${ }^{43}$.

Esta cuestión se comprende mejor al comparar la obra de Sahagún con la de su hermano tlaxcalteca. Siguiendo a Cicerón y a Aristóteles, nos habla Diego Valadés sobre la necesidad de la invención o descubrimiento de los argumentos: "no es más fructuoso que concebir con la mente la forma y edificación de una casa sin tener material con qué realizarlo", 44 y añade sobre la disposición — de los materiales oratorios- que, "es conveniente que los argumentos estén en su sitio, tengan cadencia rítmica y que no parezca que fueron tomados de otra parte sino que nacieron de los mismos argumentos verdaderos" $" 45$ para luego de encontrados y dispuestos venga la elocución o acomodación de palabras idóneas y claras sentencias a la invención, pues "así como la disposición pone en su lugar los diferentes huesos por medio de los ligamentos, la elocución añade la carne y la sangre, el color y figura" 46 . En esta misma tónica, el Florentino puede considerarse un instrumento para la conversión en la medida en que recopila material con qué edificar discursos a la manera indígena, para que no parezcan ajenos ni mal dispuestos y resulten más fácilmente asimilables.

Sin embargo, y pese a que seguramente ambos franciscanos compartieron la misma concepción sobre la retórica, Sahagún no expuso normas ni ejemplos en su texto, ni tampoco hizo un recuento de la retórica de su tiempo, sus partes y modos, a la manera de Valadés. En vez de ello,

\footnotetext{
${ }^{42}$ Bernardino no exhibe normas y usos retóricos; en vez de ello, transcribe muestras de los discursos indios a partir de los cuales pueden entresacarse formas discursivas y contenidos morales útiles para evangelizar.

${ }^{43}$ Louise BURKHART ha reconocido el uso del náhuatl clásico como lengua de la interacción. Cfr. The slippery Earth: nahua-christian moral dialogue in sixteenth-century Mexico, Tucson: University of Arizona Press 1989.

${ }^{44}$ VALADÉS: Retórica cristiana, pp. 189-191.

${ }^{45}$ VALADÉS: Retórica cristiana, p. 205.

${ }^{46}$ VALADÉS: Retórica cristiana, p. 205.
} 
reunió propiamente discursos y la materia para construirlos — vocablos e información etnográfica; textos "clásicos" provenientes de la tradición oral de los naturales (que él obtuvo con ayuda de sus estudiantes trilingües y gracias a los ancianos y sus pinturas), y a partir de los cuales extrajo sus formas discursivas. Esto es precisamente lo que constituye al Florentino como un instrumento de conversión, como herramienta para predicadores y confesores.

Un ejemplo puede ilustrar mejor este punto. En el libro XI, el Florentino reúne información sobre plantas, animales y piedras preciosas gracias a la cual elabora después discursos como el siguiente salmo sobre la Navidad, que aparece en sus obras doctrinales ${ }^{47}$ :

Maravillémonos de los preciosos ámbares como quetzal de los jades preciosos que se esparcieron, se dispersaron, que cayeron en la tierra de Belén ${ }^{48}$.

Otro fragmento que trata contenidos cristianos bajo un ropaje indio ayuda a esclarecer mejor esta idea:

Esto es como la siembra de semillas, el soterramiento pues tu alma es el terreno de cultivo espiritual, y has de cuidar bien la mata de maíz espiritual, el ya dicho mantenimiento de los mandamientos divinos y la aceptación de las virtudes como modo de vivir. Pero en cuanto a los que sólo son pecados, los que sólo son yerbas, zacates, tapates, chicalotes ique no vayan a crecer, que no vayan a nacer las plantas, que no vayan a sazonarse! ${ }^{49}$

${ }^{47}$ “No, cierto, es la menos noble joya de la recámara de la predicación evangélica el conocimiento de las cosas naturales, para poner exemplos y comparaciones, como vemos el Redemptor haberlo usado. Y estos exemplos y comparaciones, cuanto más familiares fueren a los oyentes, y por palabras y lenguaje más usadas entrellos dichas, tanto serán más eficaces y provechosas" CF, prólogo al libro XI.

${ }^{48}$ Bernardino de SAHAgún: Psalmodia christiana, ed. José Luis Suárez Roca, León: Instituto Leonés de cultura 1999, p. 415.

${ }^{49}$ SAHAGÚN: "Apéndice a la postilla”, pp. 147-149. 
Textos como los anteriores prueban el uso de las formas, estilos y vocablos indianos en la predicación. No obstante y sin afán de ser tan insistente, la diferencia específica en nuestro autor, está dada por la integración de los propios discursos mexicanos a la predicación cristiana. Efectivamente, los discursos de los indios podrían ser medio que los misioneros usaran en su proyecto de conversión, pues así como san Agustín en su De Doctrina Christiana libro 2, cap. 40, afirmaba que los judíos se habían servido de los vasos sagrados egipcios para su propio culto, de igual forma, concedía Sahagún, debían servirse los cristianos de los medios profanos para su propia utilidad ${ }^{50}$. Como la retórica de los antiguos mexicanos, su arte persuasivo y oratorio continuaban ligados a la dimensión social y cultural de los naturales, la familiaridad y la cercanía con sus propios modos discursivos (las metáforas y exhortaciones usadas antes de la conquista) harían posible un cristianismo más sólido en los neófitos americanos.

Un ejemplo que muestra los contenidos indianos bajo la luz del cristianismo aparece en el Apéndice a la Postilla. En dicho escrito Sahagún, anteponiendo la afirmación "lo manda la Sancta Madre Iglesia", despliega exactamente igual, en el mismo orden y disposición, el discurso que en el Florentino ocupa el capítulo XXII del libro VI, en que se contiene la doctrina que el padre principal daba a su hijo acerca de la policía exterior:

[P]rimeramente, habéis de ser los que se despiertan de dormir, los que están velando, no os habéis de dar mucho al sueño, para que no sea dicho de vosotros, para que no seáis dado nombres como sois capullos de gusano, sois entorpecidos por el sueño, estáis envueltos en sueño. Habéis de

\footnotetext{
${ }^{50}$ San Agustín es de los pocos autores que Sahagún cita en su trabajo: "A este propósito en este tercero libro se ponen las fábulas y ficciones que estos naturales tenían cerca de sus dioses, porque entendidas las vanidades que ellos tenían por fe cerca de sus mentirosos dioses, vengan más fácilmente por la doctrina evangélica a conocer el verdadero Dios, y que aquellos que ellos tenían por dioses no eran dioses, sino diablos mentirosos y engañadores". CF, prólogo al libro III.
} 
madrugar, habéis de pasar la noche velando. Habéis de dar suspiros $^{51}$.

\section{IV}

Al parecer, los frailes españoles buscaron en América la restitución de las pérdidas cristianas en Europa; su idea era compensarlas con aquellos a quienes lograran convertir en estas nuevas tierras. Bajo tal idea, nuestro autor asumió la responsabilidad de salvar las almas de los indios, de llevarlos al cielo. Sin embargo, sabía que esta tarea requería mucho más que la enseñanza de los dogmas y doctrinas de la fe cristiana, pues se necesitaba la acción libre y voluntaria de los hombres americanos para cumplir la ley de Dios y adherirse a la nueva religión. En este contexto, Bernardino concibe su obra como solución a la falsa ilusión de las primeras conversiones, para él, tan rápidas como ineficaces ${ }^{52}$.

Llegados a este punto me parece importante reconocer que Sahagún no distinguía ninguna incapacidad de los naturales, quienes no serían "menos hábiles para nuestro cristianismo si fueran en él debidamente cultivados". Por el contrario, el seguidor del Poverello atribuía toda responsabilidad a los evangelizadores, y como solución propone a las nuevas generaciones de misioneros el método del que venimos hablando, surgido de la convicción de que el indio debía aprender, con asimilación personal moral, los nuevos preceptos del cristianismo. Incorporando una tesis clave del también franciscano, Juan Duns Escoto; ${ }^{53}$ la metodología

\footnotetext{
${ }^{51}$ SAHAGÚN: "Apéndice a la postilla", p. 105

${ }^{52}$ Sahagún nos deja ver su desencanto ante la conversión indiana de finales del XVI en varios escritos; baste recordar el prólogo al libro I de su Historia universal, donde nos dice: "los pecados de la idolatría y ritos idolátricos y supersticiones idolátricas y agüeros y abusiones y ceremonias idolátricas no son aun perdidas del todo"; el prólogo al libro II donde añade que "el diablo ni duerme ni está olvidado de la honra que le hacían estos naturales y que está esperando coyuntura para volver al señorío que ha tenido" y la relación del autor digna de ser notada del libro X cuando se lamenta sobre lo poco que han aprovechado el cristianismo.

${ }^{53}$ Según Miguel MATHES, la biblioteca de la Santa Cruz contaba con un ejemplar de las Quodlibetales de Escoto. (Cfr. Santa Cruz de Tlatelolco: la primera biblioteca académica de América, México: Secretaría de Relaciones Exteriores 1982.
} 
consistía en recuperar los discursos de la antigua cultura para rescatar las formas discursivas y los contenidos que no fuesen idolátricos y, a partir de ello, introducir algunas tesis cristianas en medio de lo propiamente indiano. Dicho de otro modo, Sahagún buscaba un procedimiento que permitiera la verdadera asimilación de la doctrina cristiana como propia.

Es verdad que la mayoría de los franciscanos buscaron de algún modo esta evangelización inculturada, pero Sahagún tiene el mérito de señalar con valentía el problema de los malentendidos y la ocultación de la idolatría en medio de las metáforas, los movimientos corporales, los alimentos y otras muchas disposiciones y creencias culturales de los indios.

Si la preocupación sahaguntina se concentraba en alumbrar a los indios de "las tinieblas de la idolatría" e introducirlos en la Iglesia Católica para que "alcancen el reino de los cielos", 54 es decir, convertirlos y salvarlos, es comprensible que se angustiara por la dificultad de esta tarea en la que los indios habían de participar activa y sinceramente: a través de su voluntad por conocer la doctrina cristiana, creyéndola y asimilándola como propia, pero sobre todo, actuando en consecuencia para merecer el cielo.

En un contexto en el que el indio se sentía traicionado por su propio Dios (al que siempre se había mantenido fiel), abatido psicológicamente por la sistemática destrucción de todo lo que siempre había amado y venerado; probablemente consumido por la tristeza y sin interés por la vida, todo era muy difícil para los misioneros, y más aún, si consideramos las diferencias categoriales entre indios y españoles y su manera de abrazar la $\mathrm{fe}^{55}$.

\section{V}

Pongamos especial atención en el siguiente punto: ¿Cómo podría Sahagún incitar a los indios a creer y asimilar como propia la nueva religión y sus preceptos? El primer paso, indispensable para Bernardino,

\footnotetext{
${ }^{54}$ SAHAGÚn: Historia General..., p. 720.

${ }^{55}$ Louise Burkhart hace una interesante reflexión sobre la moralidad en ambas culturas, pues los indios no consideraron la existencia de absolutos morales, vale la pena verlo en The slippery Earth..., pp. 26-27.
} 
estaría en evitar la ruptura entre la nueva doctrina y las verdades tradicionalmente aceptadas por los indios. ¿Cómo evitarla? Partiendo del rescate de las tradiciones de la antigua cultura para después interpolar en ellas cierto contenido cristiano, y finalmente, utilizarlas como instrumento que moviera a la conversión y al actuar moral.

En el presente trabajo suponemos que Sahagún toma una tesis de Escoto para resolver la cuestión. Revisemos las palabras de este último para entender mejor la tesis que suponemos toma de él Sahagún:

Aunque en algún objeto se da toda perfección, sin embargo, para la necesidad del acto se requiere que la potencia tienda necesariamente a él. Sea lo que fuere de la voluntad creada bienaventurada y de su perfección sobrenatural, por la que tiende a tal objeto, con todo, se diría que la voluntad del viador tiende sólo contingentemente a él, incluso cuando lo aprehende en su universalidad. Pues esta aprehensión no determina a la voluntad a quererlo necesariamente, ni, puesta la aprehensión, se determina necesariamente la voluntad ${ }^{56}$.

Siguiendo al Doctor Subtilis, Bernardino pone el énfasis en la voluntad, no siendo suficientes el conocimiento de la doctrina y el cumplimiento "imitativo" de las normas que ésta dicta. Los actos de los indios serían verdaderamente morales y piadosos sólo si actúan por convicción propia, movidos más bien por el propio deseo y la rectitud interior.

La tesis escotista que considero sigue Sahagún, implica que para garantizar la moralidad de una acción, el indio converso debe ser capaz de juzgar por sí mismo, en conciencia propia, la conveniencia de llevarla a cabo o no; que de hecho actúe rectamente por conocimiento y decisión propia, y no siguiendo el consejo del fraile ni obedeciendo ciegamente los mandatos de la Iglesia ${ }^{57}$. El punto clave de la conversión genuina estaría en asumir que la bondad moral en el obrar indígena depende de su

\footnotetext{
${ }^{56}$ John Duns Scotus: Questiones quodlibetales, Madrid: Católica 1968, p. 20 , c. 16 , a. 1.

${ }^{57}$ Escoto entiende la moralidad de las acciones distinguiendo entre acto interno y acto externo. Cfr. Scotus: Questiones quodlibetales, p. 12, c. 18.
} 
interior, de su adhesión voluntaria y libre al bien actuar, y no del simple acto externo.

Evitar estas rupturas en el proceso de asimilación de la doctrina cristiana, cuestión obviamente nada sencilla, conllevaba grandes cambios en la cosmovisión indiana desde varios puntos de vista. Aquí sólo revisaremos dos de estas implicaciones:

\section{Implicaciones gnoseológicas}

El universo indiano, concebido como un conjunto conformado por la tierra y el más allá, constituido por trece cielos y nueve infiernos, se hallaba sometido al devenir cíclico y a la destrucción continua. En esta sucesión de períodos constantes e inestabilidad universal se basaban las creencias sobre la vida y la muerte de los antiguos indígenas -incluso los dioses se sacrificaban para que siguiese fluyendo la energía cósmica ${ }^{58}$. Así, las consecuencias gnoseológicas del enfrentamiento del mundo precolombino y el cristiano serían brutales:

1. La inestabilidad del universo ${ }^{59}$ sería sustituida por un mundo estable que dependía de la voluntad (también estable) de un único Dios omnipotente.

2. La periodicidad cíclica temporal, ${ }^{60}$ intercambiada por la sucesión de momentos diferenciados (entre el antes y el ahora), encaminados al cumplimiento de un plan salvífico universal; es decir, la introducción de una historia lineal sucesiva.

\footnotetext{
${ }^{58}$ Mircea EliADE: Historia de las creencias y las ideas religiosas, Barcelona: Herder 1999.

${ }^{59}$ Los sacrificios humanos, por ejemplo, eran una manera de evitar el cataclismo y de devolver la armonía a la inestabilidad universal: "Para que las tinieblas no queden pesando definitivamente sobre el mundo, es necesario darle cada día su alimento [...] sin él, la vida misma del universo se detiene". Jacques SoustelLE: La vida cotidiana de los aztecas en vísperas de la conquista, México: FCE 2000, p. 102.

${ }^{60}$ Se trataba de una periodicidad en el terreno de lo posible, lo meramente fáctico, donde no existía la necesidad, sino sólo la contingencia, el devenir cíclico, la periodicidad de un tiempo a la vez reiterativo y predeterminado en oposición a la necesidad del mundo cristiano. Cfr. Serge GruZINSKI: La colonización de lo imaginario, México: FCE 2001, p. 95; CF, libros V y VII; LEÓn-PorTILla: Toltecáyotl, pp. 180-190.
} 
3. Las creencias sobre la muerte y el más allá, sustituidas por otras nuevas y diferentes, entre las cuales destacaba predominantemente la existencia de un solo cielo ${ }^{61}$ al que se accedía por las buenas obras.

\section{Implicaciones vitales}

La superposición de las nuevas concepciones a las antiguas, también traerían consigo cambios en la conducta de los neófitos:

1. La vinculación individual con el pasado colectivo, y la predestinación calendárica frente a la responsabilidad personal, que implicaba que el hombre fuera completa y no parcialmente libre ${ }^{62}$.

2. El cambio valorativo de las acciones, de un valor basado en el presente y la funcionalidad sociopolítica, ${ }^{63}$ hacia un valor escatológico fundado en el anhelo de un más allá que reorientara toda la perspectiva humana ${ }^{64}$

\footnotetext{
${ }^{61}$ Los trece cielos nahuas quedarían reducidos a uno. Veamos la clasificación de León Portilla basada en el Códice Vaticano A, 3738. f. 2, r: 1. Ilhuícatl metztli, 'donde avanza la luna'. 2. Citlaco, 'el lugar de las estrellas'. 3. Ilhuícatl tonatiuh, 'el cielo del sol'. 4. Ilhuícatl huitztlan, 'el cielo de Venus', relacionado con Quetzalcóatl. 5. El cielo de las citlalin popoca o las 'estrellas humeantes'. 6 y 7. El cielo de la noche o el día. 8. El lugar de las tempestades. 9, 10 y 11. Teteocan, 'el lugar donde viven los dioses'. 12 y 13. Omeyocan, 'el lugar de la dualidad'.

${ }^{62} \mathrm{El}$ porvenir de los individuos se ordenaban por el pasado colectivo; es decir, su pasado y futuro eran revelados por el calendario y la adivinación frente a una realidad cíclica. Más que decidir libremente "qué hacer", el hombre náhuatl interpretaba "cómo saber". Esto lo explica mejor Tzvetan Todorov: "la interpretación de cada hecho se hacía en función del orden preestablecido, y se debía establecer en función de la armonía universal, no de las decisiones personales de cada individuo (aunque el problema de la libertad no quede claro, parece que el hombre náhuatl es parcialmente libre, conserva cierto margen de libertad, pero depende del signo en el que nace y de la voluntad de los dioses)". Cfr. Tzvetan Todorov: Las morales de la historia, Barcelona: Paidós 1993, pp. 193-202.

${ }^{63}$ En cierto sentido es lo que Klor de Alva llama el localismo indígena.

${ }^{64}$ Tomás Trigo: "Escatología y especificidad de la ética cristiana", en César Izquierdo et.al. (comp.): Escatología y vida cristiana, Pamplona: Eunsa 2002, pp. 197.
} 
3. La irrupción de la noción de caridad en el actuar humano: los buenos actos serían aquellos que se han hecho por amor ${ }^{65}$.

4. La noción de pecado.

Sin afán de resolver la cuestión y sólo para ejemplificar, me centraré únicamente en dos cuestiones: una gnoseológica, el cambio de creencias sobre la muerte, y la otra vital, el valor escatológico de la acción.

\section{a) El cambio de creencias sobre la muerte}

Meditad, recordad la región del misterio:

Allá su casa es: en verdad todos vamos

Adonde están los descarnados, todos nosotros los hombres,

Nuestros corazones irán a conocer su rostro ${ }^{66}$.

El análisis de textos como éste nos inclina a pensar que para los antiguos mexicanos el alma sí era inmortal y trascendía la muerte, ya fuera en el cielo o en el infierno. Sin embargo, la vida que seguía al último suspiro no era el resultado de un juicio moral como en la tradición cristiana: ni el cielo era recompensa ni el infierno castigo. Al parecer, nada importaban el modo de vida de los hombres, sino las circunstancias en las que habían muerto ${ }^{67}$.

Así las cosas ¿qué pasaba con las personas después de muertas? ¿A dónde iban? O más precisamente, ¿̇ajo qué criterios se definía la morada última de su alma? Bernardino de Sahagún apunta una respuesta en el

${ }^{65}$ "Es necesario que seamos espantados para que debidamente hagamos lo que es bueno, lo que es recto, sólo por amor de nuestro señor Dios". SAHAGÚN: "Apéndice a la apostilla", p. 86 y 87.

${ }^{66}$ De los cantares mexicanos, México: Biblioteca Nacional 1904, Ms. fol. 61, v.

${ }^{67} \mathrm{Cfr}$. CF, apéndice al libro III, cap. 1-3. A Laurette Séjourné no le queda tan claro que el destino en el otro mundo se determinara sólo por la manera accidental de morir, le parece que conforme a la educación moral indígena, el comportamiento durante la vida debía tener consecuencias sobre el destino del alma después de la muerte. Cfr. Laurette SÉjounrné: Pensamiento y religión en el México antiguo, México: FCE 1987, p. 77. 
Florentino basado en los testimonios de sus informantes ${ }^{68}$. Haciendo referencia al mictlan, en el apéndice al libro III, el fraile seráfico nos dice:

[T] odos nosotros iremos allá, y aquel lugar es para todos, y es muy ancho, y no habrá más memoria de voz. E ya os fuiste al lugar oscurísimo que no tiene luz ni ventanas, ni habéis más de volver ni salir de allí.

Aunque el texto indica que aquel lugar es "para todos" y "allá iremos a parar", más adelante en el capítulo II del mismo apéndice, nos habla de otros destinos donde las almas también podían conducirse: el paraíso terrenal o Tlalocan, "en el cual hay muchos regocijos y refrigerios, sin pena ninguna. Nunca jamás faltan las mazorcas de maíz verdes, y calabazas y ramitas de bledos y axi verde y xitomates, y frisoles verdes en vaina, y flores" adonde iban quienes morían en circunstancias muy particulares, pues van allá "los que matan los rayos o se ahogan en el agua, y los leprosos y bubosos y sarnosos, y gotosos e hidrópicos" .

En el siguiente capítulo, el III del Códice de Florencia, aumenta la información:

La otra parte a donde se iban las ánimas de los difuntos es el cielo donde vive el Sol. Los que van al cielo son los que mataban en las guerras y los captivos que habían muerto en poder de sus enemigos. Unos morían acuchillados; otros quemados vivos; otros acañavereados; otros aporreados con palos de pino; otros peleando con ellos; otros atábanlos teas por todo el cuerpo y poníanlos fuego, y ansí se quemaban. Todos éstos dizque están en un llano y que a la hora que sale el Sol alzaban voces y daban grita, golpeando las rodelas $[\ldots]$ Y en el cielo hay arboleda y bosque de diversos géneros de árboles. Y las ofrendas que les daban en este mundo los vivos iban a su presencia, y allá las recibían.

\footnotetext{
${ }^{68} \mathrm{Cfr} . \mathrm{CF}$, prólogo al libro 2, fol. $3 \mathrm{v}$
} 
Y después de cuatro años pasados, las ánimas destos defunctos se tornaban en diversos géneros de aves de pluma rica y color, y andaban chupando todas las flores ansí en el cielo como en este mundo, como los zinzones lo hacen.

De las muchas regiones donde el alma podía resguardarse tras la muerte, los frailes novohispanos solían comparar el mictlan con el infierno y el Tlalocan con el paraíso. Sin embargo, el mictlan, la región de los muertos, no era un lugar de castigos y horrores, sino simplemente una morada para quienes habían terminado su existencia terrenal, quienes se encaminaban hacia el Norte, para continuar su vida junto a Mictlantecuhtli y Mictecacíhuatl. De la misma manera, llegar al paraíso terrenal, Tlalocan, lugar de placeres y bonanzas, no dependía sino del capricho de Tlaloc, pues a él iban quienes morían por causa de las aguas ${ }^{69}$. Para los cristianos en cambio, el destino del alma después de la muerte no tenía nada que ver con caprichos divinos. Su Dios era estable y había dictado normas claras que seguir para alcanzar la vida eterna; por ello estaba en estrecha relación con las obras humanas. El paraíso estaba reservado para el justo y bienaventurado; los pecadores, iban al infierno.

\section{b) El valor escatológico de la acción}

Bajo estos presupuestos, si el hombre náhuatl se interesaba por ganarse el cielo y evitar los castigos infernales, necesariamente habría de cambiar no sólo sus nociones fundamentales de teología, sino también sus hábitos de vida. El valor de las acciones humanas no se debía buscar ya con fines político-sociales, sino con fines escatológicos. Con ello, el indio precortesiano se enfrentaba a la idea de un más allá todavía desconocido pero reorientador de toda su perspectiva humana: además del valor que tenían en el ámbito social y político de su comunidad, sus acciones — ahora "cristianizadas" — tendrían un valor salvífico personal.

\footnotetext{
${ }^{69}$ Hidrópicos, ahogados, por muerte de rayo... (Cfr. Paul Westheim: Arte antiguo de México, México: Biblioteca Era 1991, p. 66.
} 
En las sociedades indígenas el individuo adquiría, desde la infancia, un sentido de su misión colectiva dentro del mundo ${ }^{70}$. La religión se desplegaba en todas las esferas sociales, culturales y políticas de la comunidad; de ahí resulta lógico concluir que los indios se apegaran, aún después de la invasión española, a las creencias y normas morales que les habían dado seguridad y funcionalidad sociopolítica a través de generaciones.

El cambio a partir de la cristianización implicaba transferir la importancia de los efectos prácticos del bien actuar a sus efectos más trascendentales. En otras palabras, lo importante estaba ahora en la salvación individual por las obras de cada uno, y no tanto en el funcionamiento de la sociedad, pues si la vida en la tierra "lugar de mucho llanto, lugar donde se rinde el aliento, donde es bien conocida la amargura y el abatimiento" $" 71$ es corta y pasajera, y son las obras el camino hacia "donde siempre es la estación de verano" y "absolutamente nadie nos quitará nuestra alegría, nuestros deleites, nuestro completo contento", ${ }^{72}$ tal vez valiera la pena seguir los mandamientos de la Iglesia ${ }^{73}$. Sahagún, como todos sus cofrades, buscaba la salvación de las almas de los indios; sin embargo, como intenté explicar antes, su preocupación era más honda que la de la mayoría. Lo primordial en él no era la urgencia en las conversiones sino la solidez y la profundidad de la fe de los nuevos cristianos. De ahí su insistencia en que las obras piadosas, es decir auténticas e íntimas, nos daban la salvación, ya no las circunstancias de la muerte ni la voluntad caprichosa de los dioses, pero tampoco, la imitación irreflexiva de las enseñanzas de los frailes.

Dice Bernardino de Sahagún:

[L]os que piensan que se les dará el reino de los cielos sólo a causa de la misericordia de Dios, aunque nada hagan que

\footnotetext{
${ }^{70}$ Wolf, Eric: Pueblos y culturas de Mesoamérica, México: Biblioteca Era 1967, p. 131.

${ }^{71} \mathrm{CF}$, libro VI, cap. XVII.

${ }^{72}$ SAHAGÚN: "Apéndice a la postilla", p. 83

${ }^{73}$ Bernardino de Sahagún: Psalmodia Christiana, ed. Arthur J. O. Anderson, Salt Lake City: University of Utah Press 1993, p. 27
} 
sea bueno y recto, son muy desatinados. Ellos no se pueden salvar. Los que andan diciendo que Dios es muy misericordioso, que nos ama a nosotros los pecadores, que murió por nosotros, que nos dará la vida eterna aunque no la merezcamos, aunque no cambiemos nuestro modo de vivir, por eso son muy desatinados. No se salvarán. En cuanto a los que se enfadan, que dicen: Dios no me concederá el reino de los cielos aunque viva bien: su desatino, su enfado, llegan a ser sus sostenes, de modo que no desean cambiar sus vidas. Aun más grande es su desatino; ellos no se pueden salvar ${ }^{74}$.

Para los neófitos americanos, salvarse era ahora un asunto de importancia. Los vicios y virtudes que antes les valían el aprecio de sus semejantes, ${ }^{75}$ ahora los podían conducir o alejar de un buen destino a la hora de morir. "Allá en el interior de los cielos, que se llama el cielo empíreo, se han juntado todos los placeres, todas las riquezas"; 76 pero “en el cielo empíreo recibirán muchos regalos del Señor nuestro Dios" sólo "si siguen al cristianismo como forma de vida"77.

Para que los naturales quisieran seguir la vida cristiana, sin que ello supusiera una ruptura con sus tradiciones, Bernardino salpica las creencias indianas con un toque de cristiandad. Veamos como ejemplo esta transmutación cristiana sobre las creencias indianas acerca de la muerte, contenida en la oración que hacían los naturales a Tezcatlipoca en tiempos de pestilencia:

Descanse ya y recójase ya vuestro coraje y vuestro enojo, que a la verdad de la muerte no se pueden escapar ni huir

\footnotetext{
${ }^{74}$ SAHAGÚN: "Apéndice a la postilla", p. 25.

${ }^{75} \mathrm{Me}$ parece que las normas morales de los antiguos mexicanos eran normas impuestas externamente, reglas que el individuo debía cumplir para el buen funcionamiento social o en aras del bien común. La vuelta de tuercas que vino con su cristianización implicaría volverlas normas internas con miras a la salvación personal de cada individuo. Esto lo prueba la descripción de las virtudes a partir de los oficios en el libro X del Códice Florentino.

${ }^{76}$ SAHAGÚN: "Apéndice a la postilla”, p. 81.

${ }^{77}$ SAHAGÚN: "Apéndice a la postilla", p. 33.
} 
para ninguna parte. Debemos tributo a la muerte, y sus vasallos somos cuantos vivimos en el mundo, y este tributo todos le pagan a la muerte. Nadie dexará de seguir a la muerte, que es vuestro mensajero, a la hora que fuere enviada, que esta muerte tiene hambre y sed de tragar a cuantos hay en el mundo y es tan poderosa que nadie se le podrá escapar. Entonces todos serán castigados conforme a sus obras $^{78}$.

Como vimos, las creencias indianas sobre la muerte no hacían referencia a ningún tipo de juicio moral, ni premio ni castigo. Las obras personales en nada afectaban el destino del alma después de morir. Así las cosas, esta última sentencia de la oración de los naturales a Tezcatlipoca parece una interpolación cristiana. Sutilmente, Sahagún intercala contenidos cristianos en el texto, pues me parece que intenta, a través de los discursos tradicionales de los mexicanos, transmitir el mensaje de la fe cristiana desde el seno de la propia cultura náhuatl, ya que sólo apelando a la tradición puede redimensionar, desde la perspectiva gnoseológica y vital, las concepciones nahuas. Con esto quiero decir que Bernardino ha querido transmitir a las nuevas generaciones de mexicanos un discurso indiano fiel en la forma, pero no en todos los contenidos, algunos de ellos, influidos por la mentalidad del franciscano y de clara impronta cristiana $^{79}$.

No quiero detenerme en la consecuente duda hermenéutica sobre cómo deben interpretarse las informaciones que recopiló Sahagún sobre las creencias de los antiguos mexicanos, entre otras cosas, porque pienso que, en el fondo, el valor de su obra consiste en ser un "diálogo intercultural" en el que, a pesar de su evidente rechazo a la religión de sus evangelizados, esboza la idea de una convivencia plural en las diferencias

\footnotetext{
${ }^{78} \mathrm{CF}$, libro VI, cap. 1.

${ }^{79}$ Vale la pena comparar, a manera de ejemplo, el pasaje del libro VI, cap. XVI del Códice Florentino.: “ $; \mathrm{Oh}$, señor, siquiera las migaxas y las sobras de lo que se ha dicho han cogido y gozado! Y es lo que se les ha caído de la mesa a los que son ricos y tienen abastanza de bienes y son nuestros señores", en clara sintonía con el pasaje evangélico de Mat. 15: 27.
} 
(si no fuera por la idolatría). Todo ello mucho antes de que el Concilio Vaticano II reconociere que en todas las religiones hay semillas del verbo y que la única manera realmente eficaz para evangelizar a los pueblos no es destruyendo sus culturas sino sirviéndose de ellas, incluso a pesar del entrecruzamiento de categorías epistemológicas y la interacción de conceptos culturales.

\section{IV}

Después de poner de manifiesto la necesidad de reinterpretar los textos del XVI novohispano quisiera volver a la propuesta retórica de Sahagún. En mi opinión, como el seráfico ha visto la confusión y resistencia de los indios a la nueva fe, ha querido volver a la tradición indiana y obtener de ella los instrumentos para evangelizar a los aborígenes; él mismo recoge en su Coloquio la manifiesta confusión y resistencia de que hablamos: ${ }^{80}$

Vosotros dijisteis

que no conocíamos

al dueño del cerca y del junto,

a aquél de quien son el cielo, la tierra.

Habéis dicho

que no son verdaderos dioses los nuestros.

Nueva palabra es esta,

la que habláis

y por ella estamos perturbados, por ella estamos espantados ${ }^{81}$.

Cualquier otro intento que no partiera de la propia cultura americana vendría a ser un añadido externo, una superposición de la nueva religión

\footnotetext{
${ }^{80}$ CD, p. 149.

81 “Anqujmjtlalhujaca / ca amo tictiximachilia / in tloque navaque / in ilhuicava in tlalticpaque. / anqujmjtalhuja / Ca amo Nelly teteu in toteuvan. / Ca yancuic tlatolli / in anqujmjtalhuia, / auh ic titotlapolotia, / ic titotetzauja. / Ca in totechiuhcava / yn oieco, yn onemjco tlalticpac, / amo iuh qujtotiuj, / ca iehoantin techmacatiuj / yn jntlamanjtiliz, / iehoantin qujneltocatiuj, / quintlaiecultitiuj, / qujn maviztilitiuj in teteu".
} 
difícilmente asimilable. Por ello Bernardino, movido por la preocupación pastoral, propone volver a los cantos de los indios, sus discursos y adagios como instrumentos de conversión.

En mi opinión el Códice Florentino muestra, al igual que san Isidoro de Sevilla en las Etimologías, a quien muy probablemente sigue en la estructuración de su texto, la convicción de que a través de la lengua se manifiesta el mundo, la cosmovisión de un pueblo ${ }^{82}$. Por ello, comprende que ésta constituye tanto un medio de conocimiento de los indios como una vía para su evangelización.

En sus Etimologías Isidoro reúne, bajo los vocablos, todos los campos del saber antiguo. Buscando en la forma y en la historia de las palabras edifica un compendio literario que propaga por todo el mundo el imaginario de la latinidad cristiana de su época. De modo análogo, Sahagún inicia (aunque ya no con intereses gramáticos) una recopilación tan ambiciosa como la isidoriana, aunque con rasgos particulares.

La elección de este modelo isidoriano no ha sido arbitraria ${ }^{83}$. El fundador del imaginario de la latinidad sirve ahora para fundar el imaginario de la antigüedad mexicana. En este sentido es que digo que el proyecto sahaguntino es literario. Veamos:

Antes, Sahagún había intentado un vocabulario trilingüe como instrumento para la conversión de los indios. Este vocabulario, hoy perdido, ${ }^{84}$ copiaba literalmente del vocabulario de romance en latín de Elio Antonio Nebrija ${ }^{85}$ las entradas en español y su equivalente latino, esperando la equivalencia mexicana. Pero las dificultades, la diferencia entre estas lenguas y las significaciones de sus términos, lo hicieron abandonar la tarea dejando incompleta la tercera columna.

\footnotetext{
${ }^{82}$ Cfr. Isidoro de SEvilla: Etimologías, intro. Díaz y Díaz, Madrid: BAC 2004.

${ }^{83}$ "La Historia general de las cosas de Nueva España, tratado singular en el que se entreteje con maestría la sabiduría mesoamericana con los moldes del pensamiento renacentista". HeRnÁnDEZ: "La Historia General de Bernardino de Sahagún a la luz de las Enciclopedias...", p. 59.

${ }^{84}$ Cfr. Pilar MÁYNEZ: "El proyecto lexicográfico de dos frailes españoles en México", Estudios de cultura náhuatl. p. 86.

${ }^{85}$ Texto de 1495.
} 
El franciscano fue avanzando en la articulación de un nuevo proyecto de evangelización desde la lengua: abandonada la empresa de este vocabulario trilingüe (con base en el diccionario latino-español de $\mathrm{Ne}$ brija como hiciera su compañero de orden Alonso de Molina ${ }^{86}$ ), probablemente siguió con la planeación de hacer un diccionario enciclopédico (sin concretarlo) al modo de Ambrosio Calepino ${ }^{87}$. El agustino usaba expresiones tomadas de la literatura latina para explicar los vocablos, es decir, daba sus significados por el uso de los términos en los principales autores clásicos. Lo mismo hará Sahagún pero fundamentándose en la oralidad de los sabios indígenas ${ }^{88}$.

Para 1558, fecha en que recibe el mandato oficial de su orden para recoger información valiosa para la conversión de los antiguos mexicanos, el proyecto literario de Sahagún es ya un proyecto maduro ${ }^{89}$. En él, el franciscano propone la "clasicalización" de la lengua mexicana y la recopilación de sus formas poéticas y retóricas para contar con un texto base sobre el cual extraer no sólo los vocablos, sino el imaginario de estos pueblos antes de la conquista. Esto convierte a Sahagún en una especie de fundador de la literatura de los antiguos mexicanos al organizar y compilar los textos de los informantes.

Bernardino tiene el propósito de reorganizar desde su seno la propia cosmogonía e imagen del universo de los antiguos mexicanos para insertarla en el plan de salvación universal, reorientando toda la tradición indiana y tomándola como instrumento para la conversión. Continuando la tradición, hablando de la antigua palabra, de sus antepasados, sus abuelos y a través de las enseñanzas que ellos mismos dejaron, replantea

\footnotetext{
${ }^{86}$ El Vocabulario de Alonso de Molina fue publicado por Juan Pablos en 1555. (Alonso contaba ya con el Arte de la lengua mexicana que su cofrade, Andrés de Olmos había concluido en Hueytlalpan en 1547 —año en que Sahagún emprende sus pesquisas - y tuvo la suerte de estar en el Colegio de la Santa Cruz en compañía de Hernando de Ribas, uno de los más destacados trilingües; además, tuvo a mano el diccionario de Nebrija, a quien sigue en su vocabulario español-latino).

${ }^{87} \mathrm{Al}$ estilo de Ambrosio Calepino (1502).

${ }^{88}$ Cfr. Pilar MÁynez: El calepino de Sahagún. Un acercamiento, México: FCE; ENEP Acatlán 2002.

${ }^{89}$ En 1547 Sahagún inició la recopilación de los discursos indianos que después conformarían el libro VI del Códice Florentino.
} 
lo bueno y lo malo para no quebrantar los nuevos preceptos cristianos, pero sin fomentar una religiosidad de superpuestos, o en otros términos, para inspirar la bondad moral desde el interior de los indios y no a través de puros actos externos.

Al no hacer tabula rasa de las tradiciones ancestrales nahuas, Sahagún está pensando en una transición religiosa pacífica mediante la aceptación voluntaria de la nueva fe, e incluso en la construcción de un nuevo cristianismo americano.

Al no haber literatura de dónde extraer los vocablos nuestro autor organiza al modo de los clásicos latinos, el maremagnum de la oralidad mexicana y construye los cimientos de donde emergerá la imagen del mundo precortesiano donde, además del europeo, el propio indígena reconocerá su pasado y su tradición. Esta es la clave: que los indios se reconozcan en los textos de Sahagún, pues a partir de ellos iniciará la evangelización inculturada de que hemos hablado.

A Sahagún le interesa rescatar la riqueza del lenguaje, la abundancia y uso de las metáforas, la precisa y elegante estructuración de las frases que usaba la clase culta de los antiguos mexicanos; por eso recoge estos huehuetlatolli, expresados en un qualli tlahtolli, "buen lenguaje", forma de hablar cuidadosa, ${ }^{90}$ de tal suerte que pueda dar muestras del mejor náhuatl y constituir la "narrativa clásica del mexicano". Son estos textos testimonio de la sabiduría ancestral, de la antigua palabra cuyo "contenido concierne a los principios y normas vigentes en el orden social, político y religioso del mundo náhuatl"; 91 se trata de pláticas dirigidas a los hijos, esposos, gobernantes, enfermos, los que han muerto, mercaderes, artesanos, etc., y también oraciones dirigidas, por ejemplo, a Tláloc pidiendo lluvia, a Tlazoltéotl, para el ritual de la purificación, a Tezcaltipoca en tiempos de peste, a favor de los pobres, entre otros. Por su contenido moral estos textos son expresión profunda del saber precortesiano acerca de lo que es y debe ser la vida humana en el tlaltipac.

Las oraciones y consejos que constituyen este nuevo género literario en lengua mexicana conservaban los mismos atributos estilísticos que

\footnotetext{
${ }^{90}$ Librado Silva Galeana (ed.): Huehuetlatolli, México: FCE 1991, p. 30.

${ }^{91}$ Silva GaleanA (ed.): Huehuetlatolli, p. 31.
} 
fray Juan Bautista hizo imprimir tras la investigación de fray Andrés de Olmos $^{92}$. Tales discursos, como los del VI del Florentino, fueron transmitidos de generación en generación, repetidos de memoria hasta que eran grabados en el corazón de los oyentes, quienes a partir de los principios que allí se enunciaban iban guiando sus vidas "como una luz, una tea que alumbra".

Veamos un ejemplo. Así los informantes de Sahagún:

Tal vez algo merezcas, tal vez honres en algo a Nuestro Señor, tal vez seas algo, tal vez no cuentes en ninguna parte; tú simplemente vive, con toda tu modestia, tu cortesía, tu humildad, tu llanto, tu pena, tu sollozo, tu renunciación y el conocimiento de tu miseria.

Mas oye todavía; entrega, consagra de verdad tu corazón a Nuestro Señor, que no nada más por de fuera se vea tu humildad, que te dirán simulador e hipócrita.

Te está viendo Nuestro Señor, el que conoce y mira el interior de la piedra y del árbol, el que conoce el corazón del hombre, el que oye y ve dentro de nosotros los macehuales; no haya mezcla ${ }^{93}$ en tu corazón, en tu humildad; como jade, como bien formada turquesa ofrece a Nuestro Señor tu humildad, y no lo hagas nada más exteriormente ${ }^{94}$.
Atla itla momacehual, at itla ticmahuizalhuiz in totecuyo; at no titlatiz, at no acan tonpohuiz; zan ximonemiti, cenca ye in motolol in momalcoch in mopilol, in mochoquiz in motlaocul in melcicihuiliz, in monecnotecaliliz, in monecnomachiliz.

Auh oc xiccaqui, huel moyollo in toconmacaz in toconilhuiz totecuyo; amo zan iyo in pani neciz in mocnoyo, ca mopan mitoz titololxochton, titlanixiquipile.

Auh ca mitzmotztiliticac in totecuyo, in tetl in quahuitl itic tlamati tlachia, in teyollo quiximati, in titic techcaqui, techitta (in) timacehualti. Maca tle xoconnenelo in moyollo, in monecnomatiliz; ma on chalchiuhti, ma on teuxiuhti, huel quizqui in xoconmomaquili totecuyo in monecnoma-

\footnotetext{
${ }^{92}$ Silva GaleanA (ed.): Huehuetlatolli, p. 34.
} 
chiliz, maca zan xitlaixpani.

Estos discursos y pláticas de los sabios ancianos descubrieron a Sahagún, fascinado por su belleza y contenido moral, un lenguaje y un modelo de discurso idóneos para la predicación evangelizadora.

Por todo esto, se puede decir que el imaginario indígena prehispánico proviene, en cierta medida, de la obra sahaguntina, la cual, al modo de las Etimologías isidorianas, trascenderá su propia época, convirtiéndolo — en palabras de Garibay- en uno de "los mejores obreros de la fundación de la cultura en México" $" 95$.

\section{Referencias bibliográficas}

- Archivo Secreto Vaticano, A. A. Arm. I - XVIII, 1816, Cartaceo. Folios 3 y $3 v$.

- De los cantares mexicanos, México: Biblioteca Nacional 1904, Ms. fol. 61, v.

- BURKharT, Louise: The slippery Earth: nahua-christian moral dialogue in sixteenth-century Mexico, Tucson: University of Arizona Press 1989.

- Bustamante, Jesús: "Retórica, traducción y responsabilidad histórica: claves humanísticas en la obra de Bernardino de Sahagún", en Humanismo y visión del otro en la España moderna, Madrid: CSIC 1992, pp. 245-375.

- DíAz Cíntora, Salvador: Huehuetlatolli: libro sexto del códice Florentino, México: UNAM 1995.

${ }^{93}$ Díaz Cíntora lo traduce por mezcla, pero se puede también entender como desorden neneloa como poner en desorden, lo cual ilustra la ley natural.

${ }^{94} \mathrm{CF}, 92 \mathrm{v}, 93$ r. La introducción es de Salvador DíAz CínTORA: Huehuetlatolli: libro sexto del códice Florentino, México: UNAM 1995, p. 82.

${ }^{95}$ Aunque tímida, la frase apoya nuestra tesis; "el obrero" ha construido la literatura mexicana. De hecho, en su Historia de la literatura náhuatl Ángel María Garibay llama a la obra de Sahagún "un monumento literario". Cfr. Ángel María GARIBAY: Historia de la literatura náhuatl, México: Porrúa 2000, pp. 561-586. 
- Eliade, Mircea: Historia de las creencias y las ideas religiosas, Barcelona: Herder 1999.

- Frost, Elsa Cecilia: Historia de Dios en las Indias. Visión franciscana del nuevo mundo, México: Tusquets 2002.

- Garibay, Ángel María: Historia de la literatura náhuatl, México: Porrúa 2000.

- González Obregón, Luis (ed.): Libros y libreros en el siglo XVI, México: Archivo General de la Nación 2002.

- GruZinski, Serge: La colonización de lo imaginario, México: FCE 2001.

- Hernández, Ascensión: "La Historia General de Bernardino de Sahagún a la luz de las Enciclopedias de la tradición grecoromana", en Bernardino de Sahagún quinientos años de presencia, México: UNAM 2002, pp. 41-60.

- Johansson, Patrick : La palabra de los aztecas, México: Trillas 2000.

- Klor DE Alva, Jorge: "El discurso nahua y la apropiación de lo europeo" en De palabra y obra en el Nuevo mundo. Imágenes interétnicas, ed. Miguel León Portilla, México: Siglo XXI 1992, pp. 338-368.

- Las Casas, Bartolomé: Del único modo de atraer a todos los pueblos a la verdadera religión, México: FCE 1975.

- LeÓn-Portilla, Miguel: Toltecáyotl. Aspectos de la cultura náhuatl, México: FCE 2003.

- — L La visión de los vencidos. Relaciones indígenas de la conquista, México: UNAM 2007.

- Martínez, José Luis: El códice florentino y la historia general de Sahagún, México: Archivo General de la Nación 1982. 
- Mathes, Miguel: Santa Cruz de Tlatelolco: la primera biblioteca académica de América, México: Secretaría de Relaciones Exteriores 1982.

- MÁynez, Pilar: El calepino de Sahagún. Un acercamiento, México: FCE; ENEP Acatlán 2002.

- —_ "El proyecto lexicográfico de dos frailes españoles en México", Estudios de cultura náhuatl, 37 (2006), pp. 85-94.

- Morales, Francisco: "Los Coloquios de Sahagún: el marco teológico de su contenido", Estudios de Cultura Náhuatl, 32 (2001).

- Motolinía, Toribio: Memoriales, ed. Edmundo O’Gorman, México: UNAM 1971.

- Pastrana Flores, Miguel: Historias De la conquista, México: UNAM 2004, pp. 25-63.

- Sahagún, Bernardino, de: Códice Florentino. Edición facsimilar del gobierno de la república del manuscrito 218-20 de la colección Palatina de la biblioteca Medicea Laurenziana, México 1979.

- - Coloquios y doctrina cristiana con que los doce frailes de San Francisco, enviados por el papa Adriano VI y por el emperador Carlos V, convirtieron a los indios de la Nueva España, ed. Miguel León Portilla, México: UNAM 1986.

- - Breve compendio de los ritos idolátricos que los indios de esta Nueva España usaban en tiempo de su infidelidad, ed. Guillermo Rousset Banda, presentación, paleografía y notas de María Guadalupe Bosch de Souza. México: s. e. 1990.

- ——: "Apéndice a la postilla", Adiciones, Apéndice a la postilla y Ejercicio cotidiano, ed. J.O Anderson, México: UNAM 1993.

- - Psalmodia Christiana, ed. Arthur J. O. Anderson, Salt Lake City: University of Utah Press 1993. 
- - Historia General de las cosas de Nueva España, ed. Ángel María Garibay, México: Porrúa 1999.

- — Psalmodia christiana, ed. José Luis Suárez Roca, León: Instituto Leonés de cultura 1999.

- Scotus, John Duns: Questiones quodlibetales, Madrid: Católica 1968.

- Séjounrné, Laurette: Pensamiento y religión en el México antiguo, México: FCE 1987.

- Sevilla, Isidoro de: Etimologías, intro. Díaz y Díaz, Madrid: BAC 2004.

- Silva Galeana, Librado (ed.): Huehuetlatolli, México: FCE 1991.

- Soustelle, Jacques: La vida cotidiana de los aztecas en vísperas de la conquista, México: FCE 2000.

- Todorov, Tzvetan: Las morales de la historia, Barcelona: Paidós 1993.

- TRigo, Tomás: "Escatología y especificidad de la ética cristiana", en César Izquierdo et.al. (comp.): Escatología y vida cristiana, Pamplona: Eunsa 2002, pp. 195-203.

- VAladés, Diego: Retórica cristiana, México: FCE 2003.

- Westheim, Paul: Arte antiguo de México, México: Biblioteca Era 1991.

- Wolf, Eric: Pueblos y culturas de Mesoamérica, México: Biblioteca Era 1967. 
